\title{
ERJ 30 years: establishment and early years
}

To the Editor:

During the 1960s and 1970s, we had in Europe an abundance of respiratory journals. They were national, or sponsored by pharmaceutical companies, or produced by private publishing companies. At the time, they could not compete with the journals published in North America.

With the new effective treatment of tuberculosis the scope of respiratory medicine was changing towards other respiratory diseases. The "old" tuberculosis journals began to publish papers dealing with these "new" diseases. This was manifested by modifying journal titles. The Acta Tuberculosea et Pneumologica changed to Acta Tuberculosea et Pneumologica Scandinavica in 1961 and then to the Scandinavian Journal of Respiratory Diseases. In 1973, we widened the scope of the Scandinavian journal by designating section editors: Björn Bake for physiology and Paul Vermeire for pharmacology.

In an attempt to reduce the abundance of respiratory journals, Prof. André Gyselen invited editors and managers from a dozen journals to a meeting in Brussels in 1978. The meeting was chaired by Paul Vermeire. However, the majority of the participants were unwilling to give up their domains.

Later that year, Paul Vermeire wrote to me:

Firstly, we decided to stop publication of the Acta [Acta Tuberculosea et Pneumologica Belgica] as an independent journal at the end of 1979 and to join another journal of respiratory medicine...

Secondly, our board has unanimously favored a fusion with the Scandinavian Journal of Respiratory

Diseases ... We hope that this fusion may be a further step towards the creation of a European journal for respiratory medicine".

The publisher, Munksgaard, accepted this proposal, and the Société Belge de Pneumologie took a joint subscription for the journal. Paul Vermeire was made associate editor.

The editorial board now represented seven countries in northwestern Europe: Finland, Sweden, Norway, Iceland, Denmark, the Netherlands and Belgium. After consultation with other editors in Europe we therefore named the new, united journal, the European Journal of Respiratory Diseases. The first issue appeared in January 1980 [1]. This lead to a marked increase of submissions of manuscripts from countries in Europe and outside of Europe.

This merging was mainly due to the initiatives from André Gyselen and Paul Vermeire, and was the first step on the way to a representative European journal.

A new journal for respiratory pathophysiology. In the 1960s there was a growing interest in the physiology of obstructive lung diseases and the pulmonary circulation, but there was no European forum for that. In 1965, The Bulletin de Physiopathologie Respiratoire, the "Bulletin", was established by Paul Sadoul and his team in Nancy, France. It was a private enterprise, supported by INSERM. The Bulletin became a forum in Europe for studies of lung function in health and disease.

One year later, in 1966, the Societas Europaea Physiologiae Clinicae Respiratoriae, SEPCR, was formed during a meeting in Prague, Czechoslovakia [2]. The council had representatives from most countries in eastern and western Europe. The Bulletin became Bulletin Européen de Physiopathologie Respiratoire.

@ERSpublications

Three respiratory journals in Europe were merged in two steps to form the ERJ

http://ow.ly/qaqk30jxg0Q

Cite this article as: Berglund E. ERJ 30 years: establishment and early years. Eur Respir J 2018; 51: 1800649 [https://doi.org/10.1183/13993003.00649-2018]. 
TABLE 1 Two disparate European journals

\begin{tabular}{lll}
\hline Interest & Mainly clinical & Pathophysiology \\
Language & English & French, or French and English \\
Ownership & Munksgaard & Societas Europaea Physiologiae Clinicae Respiratoriae (SEPCR) \\
\hline
\end{tabular}

In 1982 Paul Sadoul offered the ownership of the Bulletin to the SEPCR. The journal became the official journal of SEPCR in 1984. The new editor was Jean-Claude Yernault in Brussels. He was more open to cooperating with a clinical journal than Paul Sadoul.

Peter Howard in Sheffield, UK, then took over the management and cleaned up the affairs of the journal after a period of financial difficulty, and he moved the technical editing to an office in his home, using newly available desktop publishing techniques [3].

Two disparate "European" respiratory journals (table 1). In spite of lack of interest from the Munksgaard management, the editorial boards of these two journals established informal cooperation. In September 1985 I wrote to Per Pettersson, the journal manager at Munksgaard:

The suggestion to merge the two journals, raised at the SEPCR meeting in the Hague last summer, was met with great enthusiasm from members of the editorial boards and many other scientists present.

The Munksgaard managers then agreed to discuss a merge. At a decisive meeting at the Munksgaard company, Peter Howard argued that there should not only be a joint ownership, but that SEPCR "should also have a hand in the production". He claimed that the SEPCR could take care of a large part of the production at a lower cost. This was a surprise, or rather a shock, for the Munksgaard group: they simply did not believe that an "academician" could do the job [3].

Then the SEPCR president, Philip Quanjer, negotiated directly with Oluf Möller, the president of Munksgaard. He pointed out that Peter Howard had successfully introduced newly available desktop publishing techniques. He emphasised that the SEPCR held high scientific standards, and had members on both sides of the "iron wall", due to the fact that SEPCR was established in Prague. He also emphasised that a combined journal would publish a wider scope of respiration, both basic physiology and clinical problems. At subsequent meetings with Munksgaard representatives and the SEPCR executive board many problems were discussed, such as shared ownership, language, widened scope and the journal's name. Peter Howard and Philip Quanjer were up to date on the electronic possibilities for producing a journal. Peter Howard outlined a program using microcomputers, transfer to floppy discs, word processor and photoprint, and he predicted a 50\% cost reduction. The final agreement was signed in April 1986. To our great surprise the society was handed the whole production.

The new journal was named the European Respiratory Journal [4]. A management board was set up with Philip Quanjer representing SEPCR and Peter Howard representing the journal, and with two representatives from Munksgaard. The board elected Erik Berglund and Jean-Claude Yernault as joint chief editors for the first two years. The first volume appeared in January 1988 [4].

The successful merging of the two journals was mainly due to the efforts of Peter Howard and Philip Quanjer.

The first years of the ERJ. Submission of manuscripts was made electronically through the internet. In 1990 Paul Vermeire became chief editor [5]. Due to the increase in number of accepted manuscripts the number of issues per year was increased from 10 to 12 in 1994.

Several supplements were published, for example an issue entitled "Standardized Lung Function Testing" [6]. Peter Howard was concerned that the regular issues of the journal would be swamped with supplements, and so it was decided to publish the European Respiratory Review with Jean-Claude Yernault as editor [7]. This was followed by the establishment of the European Respiratory Monographs and the educational journal Breathe.

The creation of the ERJ was an important part of the creation of the European Respiratory Society in 1990 [8]. In 2001, the ERS became the sole owner of the ERJ.

Erik Berglund

Former ERJ chief editor, former president of SEPCR.

Correspondence: Erik Berglund. E-mail: eok.berglund@outlook.com 
Received: Feb 092018 | Accepted after revision: April 092018

Conflict of interest: None declared.

\section{References}

Berglund E, Georg J. To our readers. Eur J Respir Dis 1987; 71: 329.

Quanjer PH. The Society is coming of age. Eur Respir J 1988; 1: 1-3.

Berglund E. Peter Howard leaves the European Journal. Eur Respir J 1996; 4: 4.

Berglund E, Yernault JC. The new European Respiratory Journal. Eur Respir J 1988; 1: 1.

Vermeire P. The ERJ two years later. Eur Respir J 1993; 6: 9-10.

ERS Working Party Report. Standardized Lung Function Testing. Eur Respir J 1993; 6: Suppl. 16, 5-100.

Yernault JC. The European Respiratory Review. Eur Respir Rev 1991; 4: 1.

Junod AF, Clarke SW. The birth of the European Respiratory Society. Eur Respir J 1991; 4: 3-4. 